\title{
The Price of Winning and the Impact on the NCAA Community
}

\author{
Emily S. Sparvero \\ University of Texas \\ Stacy Warner \\ East Carolina University
}

\begin{abstract}
In many cases, athletics department spending has been spurred by a desire to field more competitive athletics programs, and it has been assumed that spending more would result in greater on-the-field success for the athletics program. However, little empirical evidence exists to support this assumption, and few studies have explored financials trends related to cost-benefit of intercollegiate athletics program. Thus, the aim of this study was to determine the relationship between on-the-field success and spending while also exploring current trends. The authors drew longitudinal data from EADA reports and then examined the association with Directors' Cup rankings at the end of these respective seasons. The results indicated that a relationship between overall expenses and on-thefield success does exist, and points to operating expenses, rather than coaching salaries and recruiting expenses, as having greatest influence on this relationship. The cost-benefit analysis and trends over time are also explored and discussed.
\end{abstract}

In the United States, intercollegiate athletics serves as a primary means for the development of elite athletes and is also considered an integral part of the student experience for athletes and spectators alike (Sparvero et al., 2008; Warner, Shapiro, Dixon, Ridinger, \& Harrison, 2011). Institutional investment in athletics is predicated on the various benefits that sport programs are believed to deliver. In the wake of various scandals and increasing budgetary constraints, this union between education and athletics has become highly criticized, and its existence is often questioned. Typically, secondary and postsecondary institutions have borne the financial responsibility for the provision of sport programs. The challenges associated with the rising cost of providing sport programs have prompted schools to seek alternative means of financing their programs. At the high school level many schools have adopted a "pay for play" model (see Cook 2012), whereby students pay a fee to participate in athletics. At the collegiate level, athletics programs may be funded through a combination of earned revenues (e.g., ticket sales, donations), optional and mandatory student fees, and subsidies from the university and (in the case of

Sparvero is with the Department of Kinesiology, University of Texas, Austin, TX. Warner is with the Department of Kinesiology, East Carolina University, Greenville, NC. 
some public institutions) from state legislatures. The challenges associated with funding sport are heavily scrutinized when the role of sport on college campuses is examined. As a result, the Knight Commission on Intercollegiate Athletics was developed in 1989 to address the role of college sport and help reform collegiate athletics.

In one of their first published reports, the Knight Commission concluded that financial integrity was one of the fundamental areas in need of reform, along with academic integrity and independent certification of athletic. In this report entitled, Keeping Faith with the Student-Athlete: A New Model for Intercollegiate Athletics, the commission stated:

An institution of higher education has an abiding obligation to be a responsible steward of all the resources that support its activities - whether in the form of taxpayers' dollars, the hard-earned payments of students and their parents, the contributions of alumni, or the revenue stream generated by athletics programs.

It is clear that financial integrity and fiscal responsibility have been and continue to be important topics to explore within the realm of intercollegiate athletics.

In response to concerns expressed in the first Knight Commission report, the NCAA introduced measures intended to curb athletic department expenditures. The association has limited scholarships, reduced the number of allowable coaches, and even tried to limit assistant coaching salaries (Knight Foundation Commission on Intercollegiate Athletics, 2001). Although the move to restrict earnings of coaches may have been well intended, it cost the NCAA over \$54 million in a lawsuit settlement, with the end result being that salaries cannot be restricted (Alesia, 2009; Lubinger, 2011). An unintended result of the cost curbing efforts was that coaching salaries escalated (Alesia, 2009). In fact in a study of 44 public universities, Clotfelter (2011) found that over a 24-year span (i.e., 1986-2010), salaries, after adjusted for inflation, increased $32 \%$ for full professors while jumping $750 \%$ for football coaches salaries. Thus far, the efforts to control the cost of intercollegiate athletics programs have been largely unsuccessful.

The NCAA restricts direct payments to players, and consequently, the resulting income earned through athletics that would accrue for players in the absence of NCAA restrictions are instead returned to the university. The result is the distribution of these payments to coaches and athletics directors in the form of increased salaries - a phenomenon that continues to be highlighted in the popular press (e.g., Brady, Upton \& Berkowitz, 2012, 2013; Powers, 2007). The cost escalation in college athletics is not limited to salaries. Athletics department budgets also clearly indicate that recruiting and operating expenses are rapidly increasing (Fulks, 2011, 2012; U.S. Department of Education, 2012). For example, the Knight Commission (2010) found that the amount spent per athlete in Division I Football Bowl Sub-Division (FBS) conferences was 4-11 times greater than the amount spent on academics for a full-time enrolled student. Although Division I athletics, particularly FBS schools, are typically cited as the biggest culprits in the athletics spending arm race, trends in Division II and III spending should not ignored. From 2004 and 2009, the median deficit for Division II schools (with football programs) increased over 40\%, \$2.84 million to \$3.98 million (Denhart \& Ridpath, 2011). At the Division III level, the average expense per student-athlete has increased by $60 \%$ for football schools and 89\% for nonfootball since 2004 (Fulks, 2012). 
As the college athletics department scandals become more high profile and budgets escalate, administrators at all levels have become more involved with budgeting, finding revenue sources, and controlling expenses (Covell \& Barr, 2010; Masteralexis, Barr, \& Hums, 2012). Subsequently, it is not surprising that dealing with financial and budgetary issues was identified as the leading cause of concern for athletic directors. Approximately $75 \%$ of the athletic directors surveyed indicated that financial challenges/budgetary concerns were their dominant stressproducing issues, both currently and in the projected future (Humphrey, Yow, \& Bowden, 2000). Athletics directors must deal with the financial pressures created by continually increasing recruiting expenses, operating expenses, and coaching salaries. These increased expenditures are legitimized on the ground that spending more money will result in greater success for an athletics program. Myles Brand, former NCAA president, summarized:

The "spend to increase wins and win to generate new revenue" spiral that has resulted for some schools in a no-holds-barred approach to recruiting and scandalous behavior is based, ironically, on an unsupportable assumption. The popular theory is that you have to increase spending to increase wins and have to increase wins to increase revenues. (Brand as cited in Yaffee, 2005)

Clearly it has been assumed that increased spending would result in more institutional wins that would in turn generate numerous tangible and intangible benefits for the institution. However, as Brand pointed out, few empirical studies have supported or even explored this assumption. There is also little evidence available to help athletics directors make informed decisions on what financial categories best to spend limited dollars, if ultimately they want to achieve greater on-the-field success.

Therefore, the purpose of this study is to explore the financial trends and athletic department expenditure and its relationship to on-the-field success. Specifically, we explore the relationship between coaching salaries, operating expenses, and recruiting expenses and on-the-field success at NCAA DI and III institutions, as well as the relative cost of on-the-field success (i.e., efficiencies). In doing so, we also analyze data from both 2003 and 2011 to identify changes over time.

\section{Evolution of Finances and Intercollegiate Athletics}

Harvard and Yale competed in what was considered the very first intercollegiate athletic event in the United States in 1852 on New Hampshire's Lake Winnipesaukee. This first interscholastic crew event foreshadowed how financial and economic issues would become a common aspect in intercollegiate athletics. The regatta was sponsored by the Boston, Concord \& Montreal Railroad Company, which wanted to host the race in New Hampshire so both teams, their fans, and other spectators would have to ride the railroad to get to the event. The railroad company covered travel and lodging for both the Harvard and Yale athletes, but likely still made a profit from the more than 1,000 spectators that were on hand for the inaugural event (Barr, 2012; Covell \& Barr, 2010). As Barr notes, "Thus, the first intercollegiate athletic contest involved sponsorship by a company external to sports that used the competition to enhance the company's business" (p. 164). 
Teams were student-run and student-organized up until 1864, when the first professional coach was hired to lead the Yale crew team. This juncture would also foreshadow the current landscapes of intercollegiate athletics. Yale athletics thrived with the move to professional coaches, and other institution soon followed suit (Covell \& Barr, 2010; Dealy, 1990). By the early 20th century, some coaches were more recognized than their university presidents and were earning salaries greater than professors (Smith, 1988). As early as 1903, Yale generated $\$ 106,000$ from college football - a sum equal to one-eighth the combined income for the university (Chu, 1989). Another significant event came in 1952 when the NCAA earned $\$ 1.14$ million from NBC in exchange for the rights to broadcast 12 football games (Byers, 1995).

There have been brief periods of limited athletic department development and spending during specific periods, including Great Depression and World War II. Still, over time, the trend in college athletics has been toward "increased spectator appeal, commercialism, media coverage, alumni involvement and funding" (Barr, 2012, p. 166). These trends show an increase in funding for college athletics programs throughout history, yet little is known about what actual gained by this increase.

\section{Intercollegiate Sport Spending and Success}

While there are multiple ways to define the "success" of an athletics program, the most prominent and visible is arguably the on-the-field success of an institution's teams, as this measure of success is regularly reported in media through results and scores. Although on-the-field success can be easily observed, little attention is paid to the costs and the corresponding return on investment associated with this type of success. University presidents recognize that the current financial model is unsustainable, and they specifically cite the growing divide between the "haves" and "have-nots," concerns over cost control, and negative effects of the financial arms race (Hesel \& Perko, 2010). Concerns over sustainability are intensified in the current macroeconomic climate, and the financial spending of institutions is under increased scrutiny.

When the financial integrity of college athletics is questioned, men's basketball and football coaching salaries are typically the first targets for journalist and researchers. This is not surprising considering "the average annual salary for (football) head coaches at major colleges (not including four schools that moved up to the Football Bowl Subdivision this season) is $\$ 1.64$ million, up nearly $12 \%$ over last season - and more than 70\% since 2006" (Brady, Berkowitz, \& Upton, 2012). Interestingly, though, scholars continue to fail to find a relationship between college coaching salaries and team performance (e.g., Orzag \& Israel, 2009; Tsitsos \& Nixon, 2012; Zimbalist, 2010). One exception to this has been Cunningham's (2003) work, which did find a relationship between head coaching salaries, assistant coaching salaries, and recruiting budgets and Sear's Cup Director point. However, it should be noted that the "expenditures for the coaches' salaries did not account for a significant portion of the variance when all three variables were considered simultaneously" (p.51).

While little evidence of a relationship between coaching salaries and winning exists, a few studies have shown that a relationship between operating expenditures and team success. For example, Orzag and Israel (2009) found a small positive and 
significant relationship between football operating expenses and football success. Specially, their data concluded an extra million dollars spend on operating expenditure for football is estimated to increase the team's winning by 1.8 percentage points and the chances of ending the season in the top 25 in the AP poll by $5 \%$. A more recent study found that institutional athletics expenditures were strongly correlated with FBS institutions' on-field performance, but not among non-FBS institutions at the Division I level (Jones, 2012). Meanwhile, Lawrence and colleagues (2012) determined that investing heavily in women's sports would most likely result in greater success for the overall department in terms Director Cup points. Thus, the few studies that have explored spending and on-the-field performance have yield mixed results.

While the finances involved in men's basketball and football are typically highlighted in the media, women's sports face issues of cost escalation similar to their male counterparts, although on a smaller scale. The win-at-all cost mentality and the feeling that monetary support is essential to remain competitive has recently become a more prominent issue in women's athletics. Top women's basketball coaches are now earning more than $\$ 1$ million (Tsitsos \& Nixon, 2012), while the median expenses per women's athletes have increased $42.9 \%$ between 2004 and 2011 (Fulks, 2011).

When Title IX was enacted in 1972, it made no mention of athletics, yet it is thought of as the single piece of legislation that has had the most lasting effect for women athletes and has changed the face of athletics. As the expenses of running a football team and a competitive men's basketball team have risen tremendously, women's expenditures across all sports have increased as a result of educational institutions attempting to comply with Title IX. Instead of reducing the dollars spent in football and basketball, administrators have chosen to increase spending on women's sports. The business of running a college athletics program no longer involves only concentrating on football and men's basketball, but rather all men's and women's sports. In addition to understanding the relationship among various budget variables, athletics directors should also be concerned with the relative efficiency of their programs. In higher education generally, there is increased pressure on institutions to demonstrate institutional efficiency (Alexander, 2000; Barr, 2004). For universities, there is increased interest in the costs and benefits of athletics, but these costs and benefits are viewed in isolation (Hesel \& Perko, 2010) instead of as a means to calculate return on investment. There is evidence of athletic directors cutting costs at the margins (Fort, 2010), but marginal reductions in spending may be insufficient in the face of either a continued economic downturn or other unexpected financial shock. Cost-benefit analysis of athletics programs provides a starting point for understanding efficiency, which is paramount to athletics directors who are pressured to remain "competitive on-the-field" with their peer institutions.

Based on this review, we developed the following research questions:

RQ1: What is the relationship among expenditures (i.e., coaching salaries, operating expenses, and recruiting expenses), success (i.e., on-the-field success), and efficiencies (relative cost of on-the-field success)?

RQ2: Are there differences between Division I and Division III universities?

RQ3: Are there changes in the relationships among expenditures, success, and efficiencies over time? 


\section{Method}

In an effort to determine the relationship between spending and on-the-field success, data were drawn from two primary sources: Equity in Athletics Disclosure database (U.S. Department of Education, 2012) and the Learfield Sports Directors' Cup rankings (NACDA, 2012). Data from 2002 to 2003 were drawn from 221 NCAA Division I and 227 Division III programs, and then 2010-2011 data were drawn from the 227 NCAA Division I and 293 Division III programs. The differences in sample are reflective of the variations in division membership during those timeframes. Data from multiple years and divisions were chosen so that trends could be explored. The years selected represent the earliest and most recently available and usable EADA data, and only institutions earning a Directors' Cup points in the given years were included.

\section{Sampling and Data}

EADA Data. The Equity in Athletics Disclosure Act of 1994, section $485 \mathrm{~g}$ of the Higher Education Act of 1965, 20 U.S.C. 1092, requires that all coeducational higher education institutions that participate in any federal student financial aid program and have intercollegiate athletics programs must provide financial information concerning their programs. Institutions are required to annually submit EADA forms to the Secretary of Education by October 15th. The Secretary of Education collects information and provides an annual report on financial and statistical information on men and women's collegiate sports to Congress each year. The EADA is designed to make prospective students aware of the school's commitment to providing equitable athletic opportunities for male and female students. EADA reports are available to the public via the Office of Postsecondary Education of the U.S. Department of Education database. The EADA data, although criticized for its accuracy, provides the most uniform indication of how much athletics departments are spending in their athletics programs. To further support this, a recent study found that although some discrepancies exist between EADA data and USA Today College Athletics Finance Database the correlation between the dataset "was an extremely high .989" (Jones, 2012, p. 11). Thus, EADA data were used to determine to the expenditures per athletics department for coaching salaries, operating expenses, and recruiting expenses.

Coaching salaries included the average wages and bonuses received from the institution. This study considered four different coaching salary variables: (1) average salary for the head coach of men's teams, (2) average salary for the head coaches of women's teams, (3) average salary for assistant coaches of men's teams, and (4) average salary for assistant coaches of women's teams. Operating expenses comprised, "all expenses an institution incurs attributable to home, away, and neutral-site intercollegiate athletic contests (commonly known as game-day expenses), for (A) Lodging, meals, transportation, uniforms, and equipment for coaches, team members, support staff (including, but not limited to team managers and trainers), and others; and (B) Officials" (U.S. Department of Education, 2012). Recruiting expenses were the expenditures an institution incurs attributable to recruiting activities (e.g., lodging, meals, telephone use, and transportation). To investigate the efficiency of athletics departments, the total athletic budget (i.e., 
combined coaching salaries, operating expenses, and recruiting expenses) were also included.

Learfield Sports Directors' Cup Rankings. As mentioned “success" can be defined in various ways. For the purposes of this study, on-the-field success was measured by the Learfield Sports Directors' Cup rankings. The Learfield Sports Directors' Cup is "a program that honors institutions maintaining a broad-based program, achieving success in many sports" (NACADA, 2012). This on-the-field success of athletics programs is accomplished by a point system that rewards postseason wins. In Division I, the top ten men's and the top ten women's sports are counted while in Division III the top nine men's and the top nine women's sports are included. Institutions competing in postseason play earn points, and the number of points earned is determined based on the size of the bracket in each sport. The total points earned at the end of the 2002-2003 and 2010-2011 seasons were then used ranked institutions (i.e., ranking of 1 received the most points earned that year).

\section{Results}

\section{Division I}

Descriptive statistics for DI budget variables using both 2003 and 2011 data are provided in Table 1. There was a significant negative correlation between Directors' Cup ranking and all selected budget variables in 2003 and 2011. Note that the negative relationships occur because better performance is associated with a lower number in the ranking; that is, the best performer is ranked \#1, and so on. The strength of these correlations was strong, with all Pearson correlations greater than -.60. Salary, recruiting, and operating expenses were all positively correlated with each other for both the 2003 and 2011 data (see Table 2).

We then examined these relationships from a multivariate perspective using regression analysis. In doing so, we (a) controlled for the size of the athletic department because that could influence its success, and (b) used the log transformations for the budget data since they were not normally distributed. For 2003 data, the first step, which controlled for the size of the athletic department, accounted for $32.2 \%$ of the variance $(p<.001)$. In the second step, the identified budget variables were entered, and they accounted for an additional $40.9 \%$ of the variance $(p<.001)$. Both models were significant predictors of on-field success, with total athletes, operating expenses, and recruiting expenses as significant predictor variables. For 2011 data, the control accounted for $33.7 \%$ of the variance $(p<.001)$, and the budget variables accounted for an additional $32.6 \%$ of the variance $(p<.001)$. In this model, total athletes, men's head coaching salaries and operating expenses were significant predictors of on-field success. Results of all predictor variables for Division I can be found in Table 3.

Next, cost-benefit analysis was used to determine to efficiency of dollars spent within an athletics department. The total athletic department budget was divided by the total Directors' Cup points earned to determine the "cost" of each Directors' Cup point. The percentage change in cost per Directors' Cup point was calculated, and the 10 most efficient and least efficient programs were identified. Descriptive statistics 


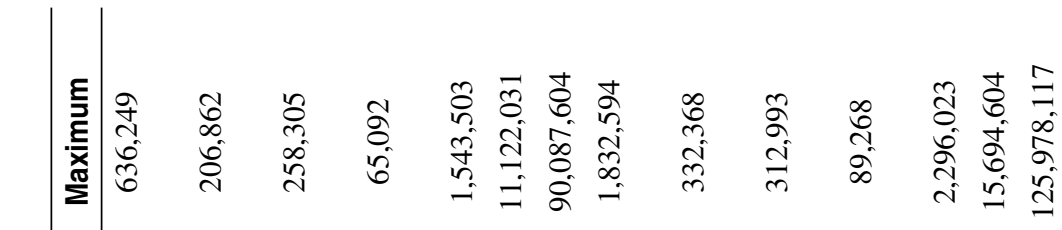

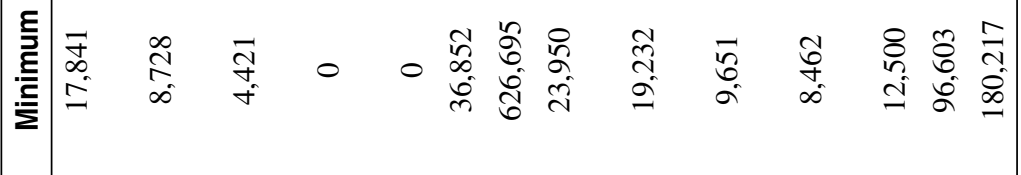

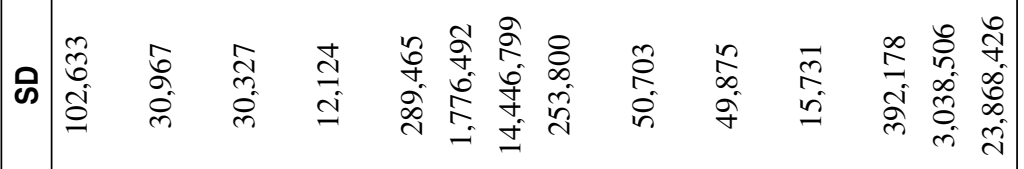

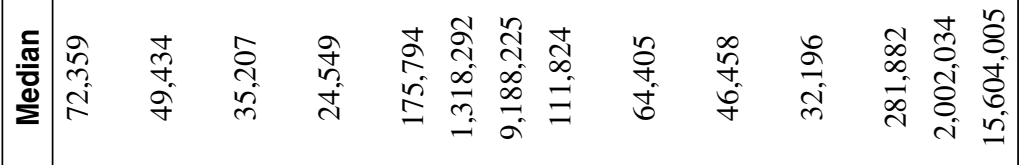

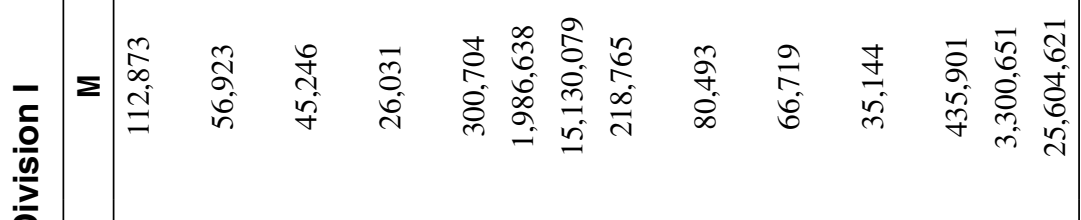

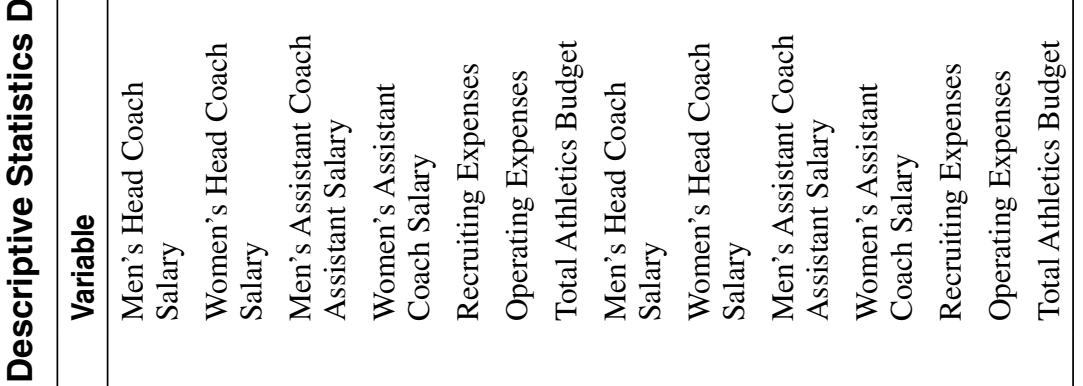

$$
\begin{aligned}
& \text { 产 } \\
& \text { స్త }
\end{aligned}
$$




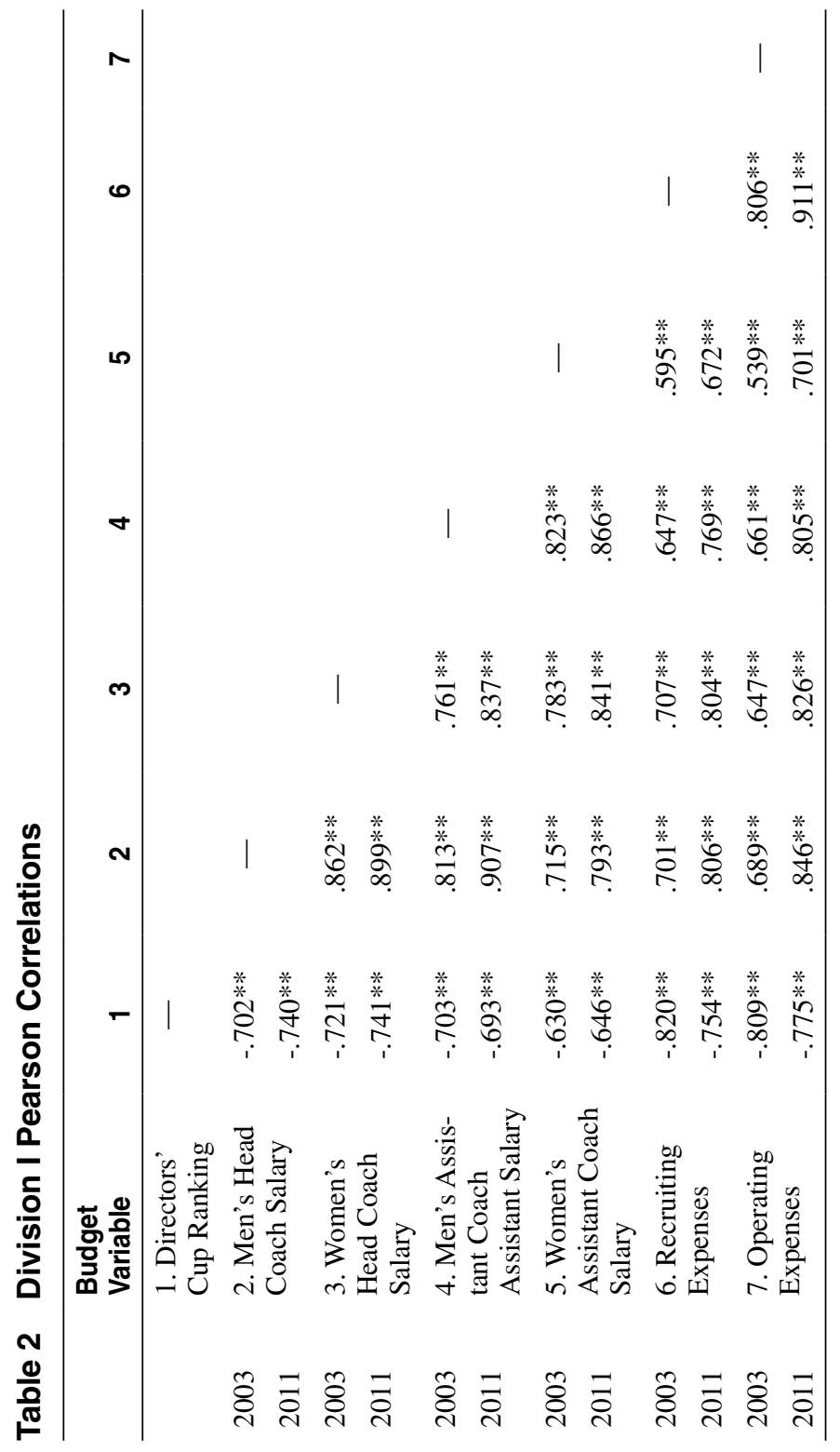




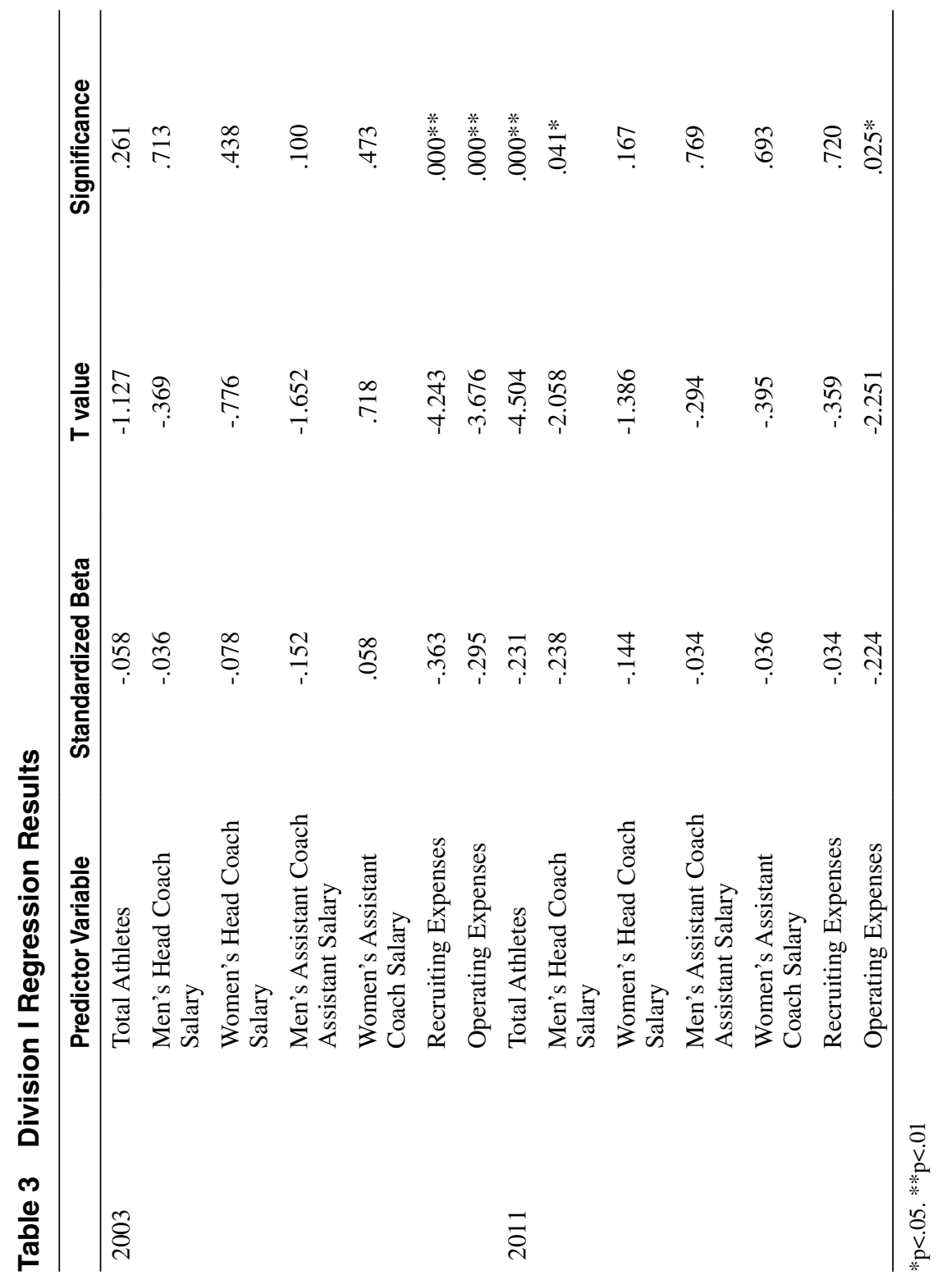


Table 4 Cost per Directors' Cup Point Division

\begin{tabular}{lccccc}
\hline & M & Median & SD & Minimum & Maximum \\
\hline 2003 & 169,953 & 121,408 & 196,262 & 24,473 & $1,642,532$ \\
2011 & 275,212 & 157,520 & 399,621 & 33,563 & $4,108,469$ \\
\% change & $61.93 \%$ & $29.74 \%$ & & $37.05 \%$ & $150.13 \%$ \\
\hline
\end{tabular}

and percent change in efficiency from 2003 to 2011 are provided in Table 4. The most efficient schools for 2003 and 2011 are listed in Tables 5 and 6, respectively. Of the 20 most efficient programs in 2003, ten schools (Duke, Stanford, Indiana, UCLA, Georgia, Arizona, Washington, UNC, Cal, and Michigan) were in the top 20 of the Directors' Cup rankings. Similarly, in 2011, nine of the 20 most efficient programs were in the top 20 of the Directors' Cup rankings (Stanford, Cal, Duke, UNC, Arizona, UCLA, TAMU, UVA, and Maryland). The most efficient programs in 2011 include six schools that were also ranked as the most efficient in 2003.

Finally, in 2011, the ACC had four of its 12 schools ranked in the top 20 most efficient, and the PAC-10 also had four of its 12 schools ranked in the 20. Conversely, in 2003, only one of the 20 schools with the largest athletics department budget ranked in the top 20 of efficiency (Michigan, with a Directors' Cup rank of 6 and an efficiency rank of 16). In 2011, the only school with a top 20 budget that also ranked in the top 20 in efficiency was Stanford (ranked 1 in Directors' Cup and 4 in efficiency). Notably, the University of Texas, which had a record-setting budget of over $\$ 1.26$ million, ranked 91st in terms of efficiency.

\section{Division III}

Descriptive statistics for Division III in both 2003 and 2011 are provided in Table 7 , and Pearson correlation analysis results are in Table 8 . There was a significant negative correlation between Directors' Cup ranking and all selected budget variables in 2003 and 2011. The strength of these correlations was relatively weak. In addition, all budget variables had significant positive correlations with the other budget variables for 2003 and 2011 data.

For 2003 data, the first model with the athletic department size control explained $32.5 \%$ of the variance in the model $(p<.001)$, and the second model explained an additional $6 \%$ of the variance $(p<.001)$. For 2003 data, the significant predictors of on-the-field success were total athletes and operating expenses, whereas in 2011, both total athletes and women's assistant coach salaries were significant. Results of all predictor variables are in Table 9.

Descriptive statistics and percentage change in cost per Directors' Cup point from 2003 to 2011 are provided in Table 10. A complete list of the 20 most efficient athletics programs are provided in Tables 11 and 12. Of the 10 most efficient programs in 2003, two schools (University of Wisconsin-Stevens Point and University of Wisconsin-LaCrosse) were in the top 10 of the Directors' Cup rankings. Similarly, in 2011, four of the 10 most efficient programs were in the top 10 of the Directors' Cup rankings (Calvin College, University of Wisconsin Stevens Point, Washington University, and University of Wisconsin-Whitewater). 


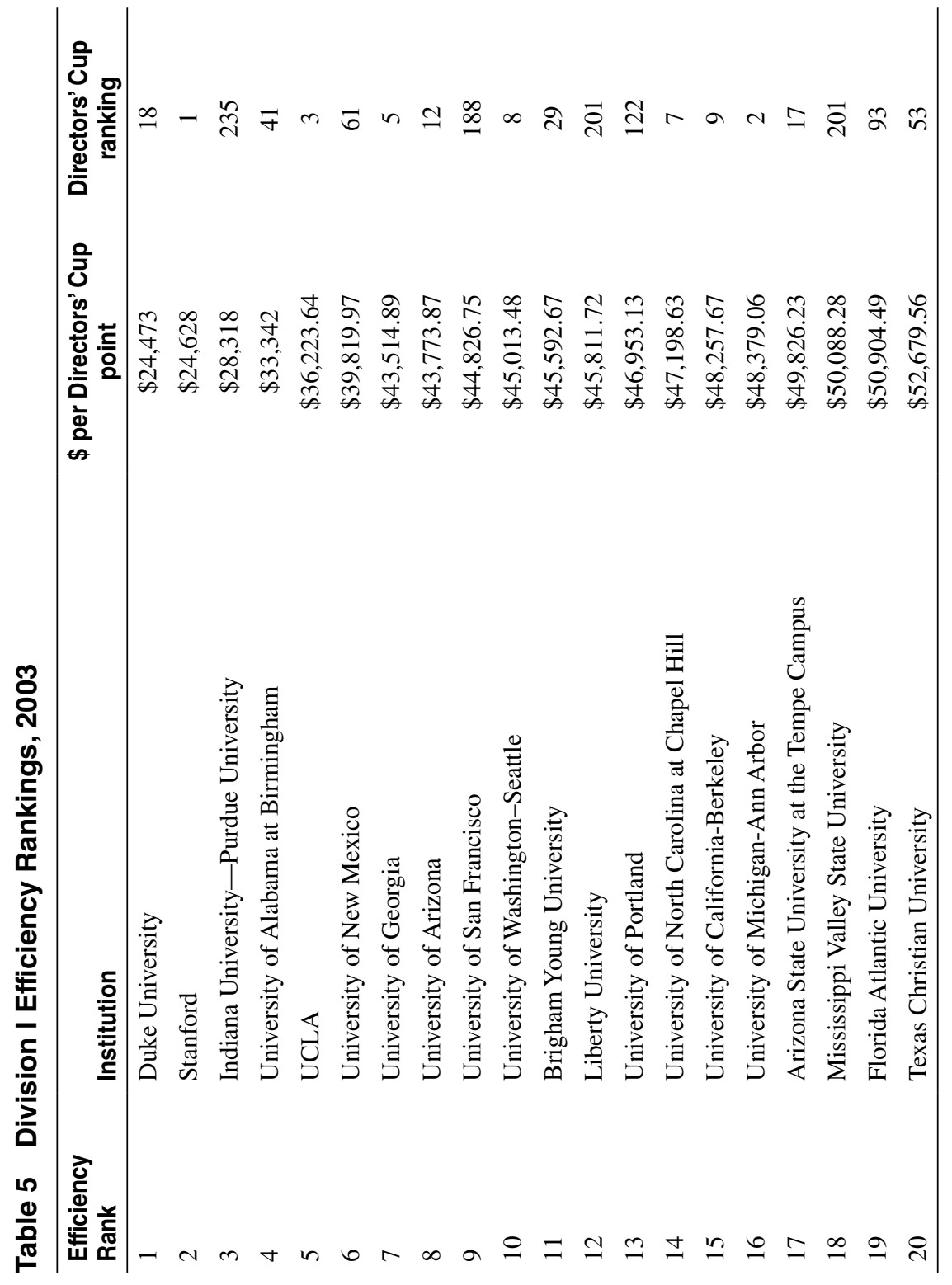




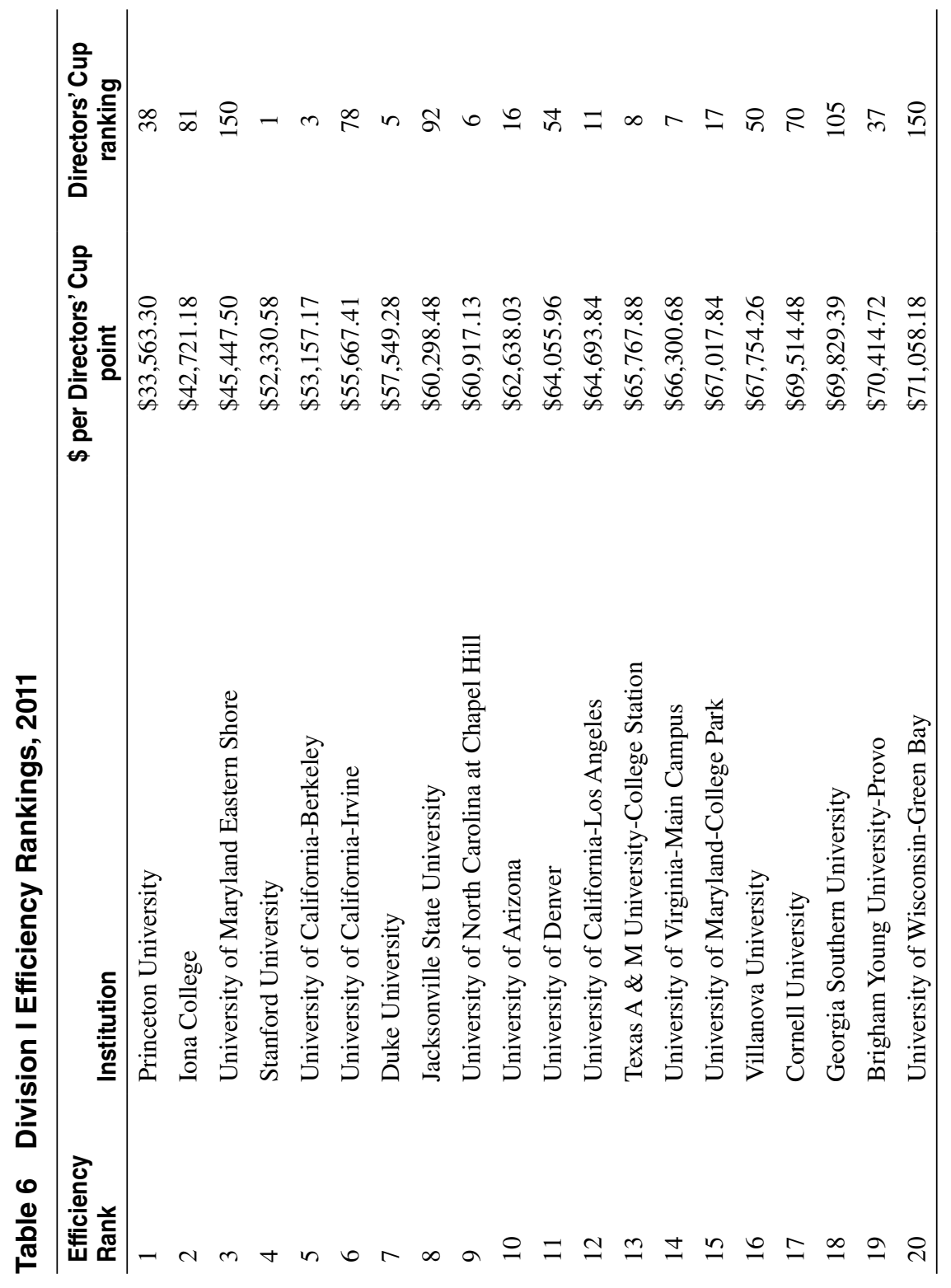




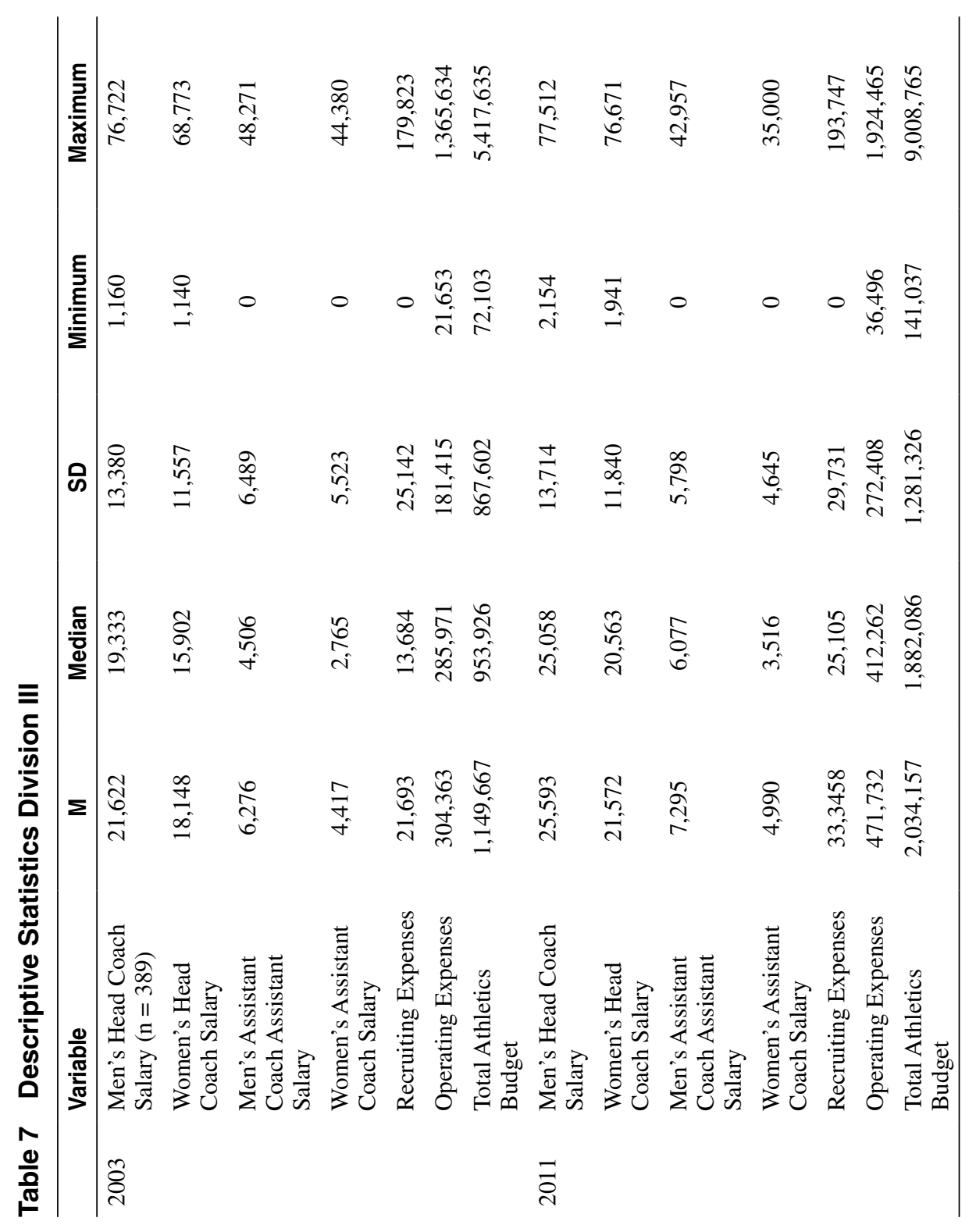




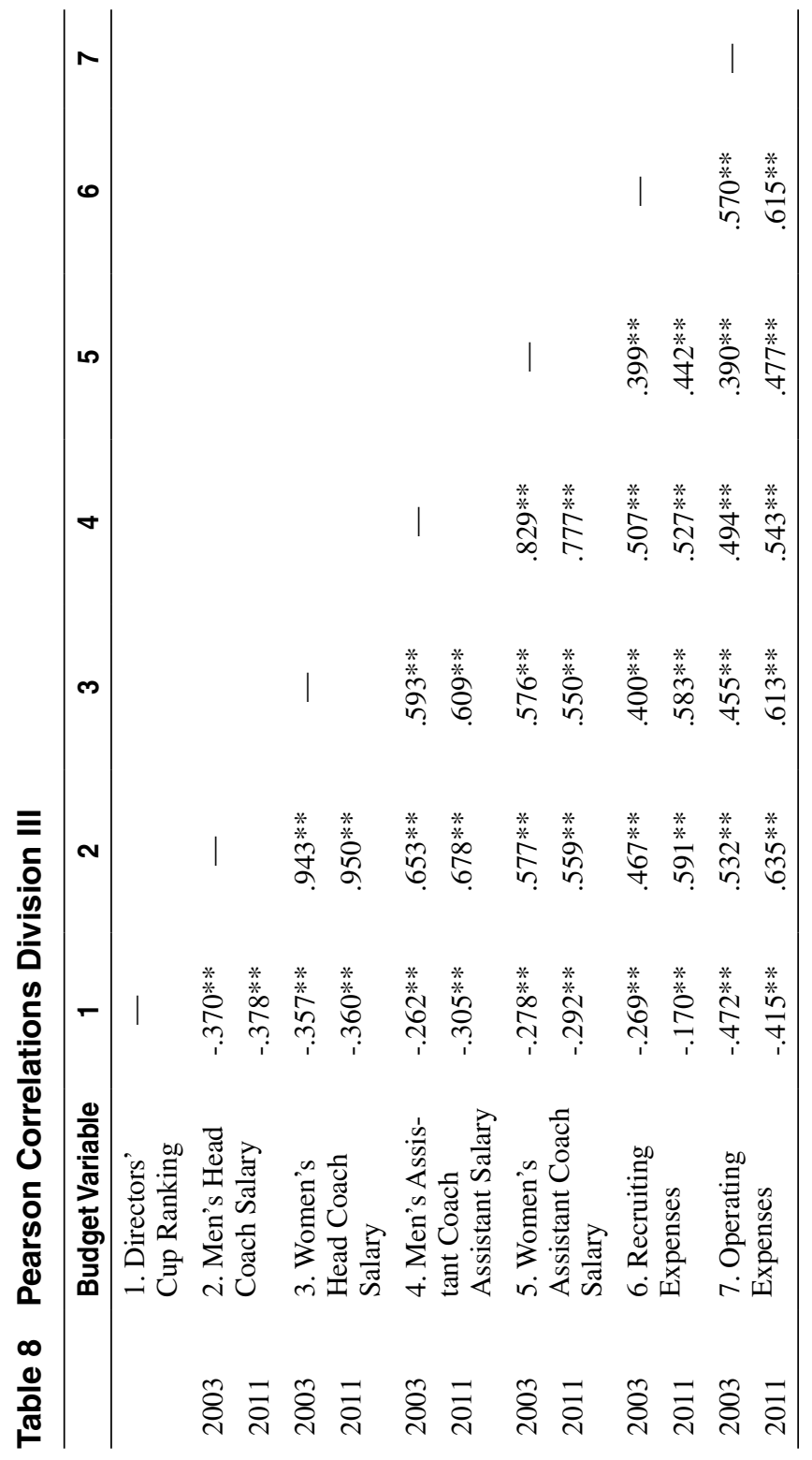




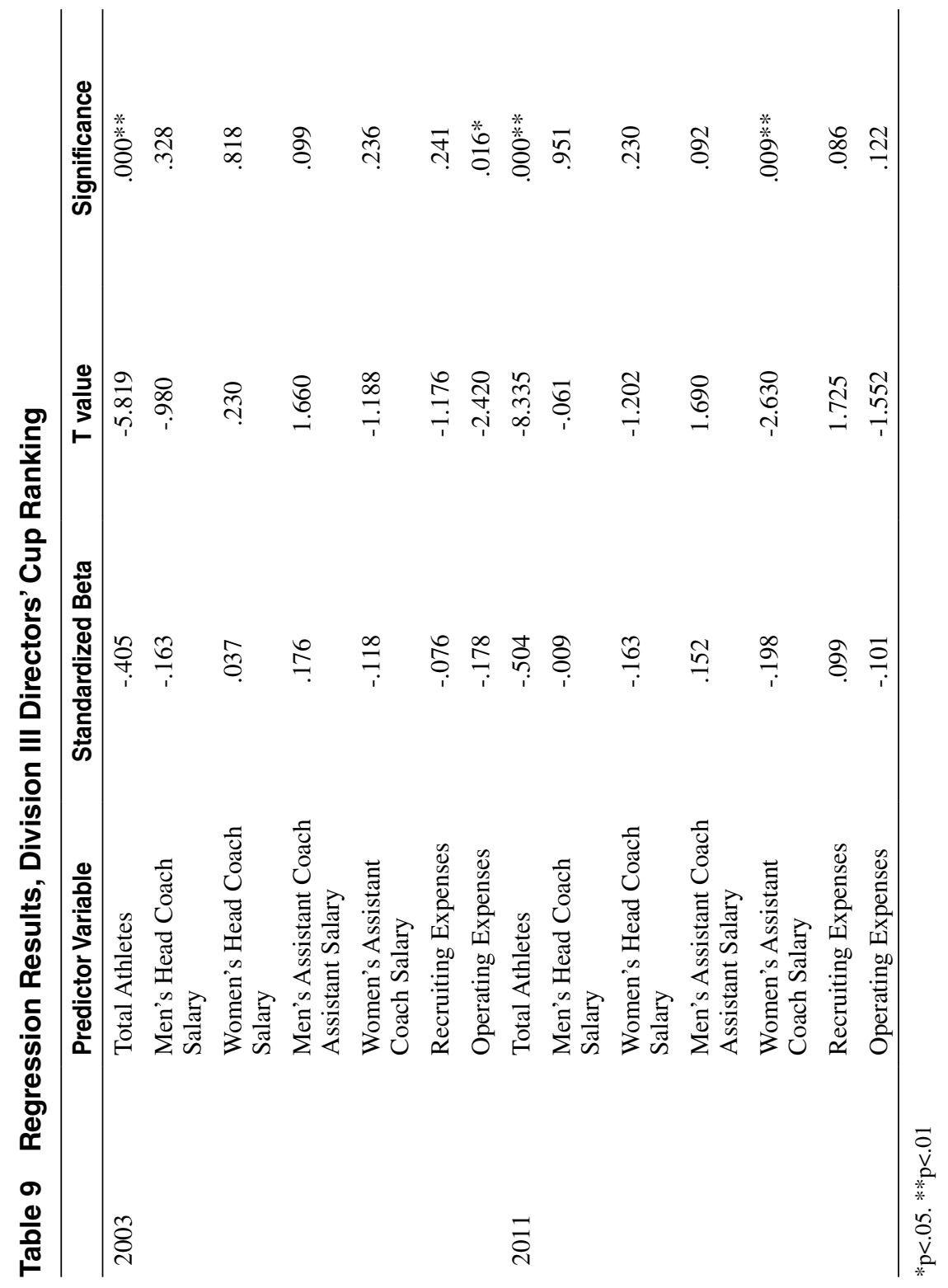


Table 10 Cost per Directors' Cup Points Division III

\begin{tabular}{lccccc}
\hline & M & Median & SD & Minimum & Maximum \\
\hline 2003 & 14,800 & 10,590 & 16,778 & 1,361 & 175,896 \\
2011 & 31,456 & 17,540 & 48,927 & 2,335 & 511,018 \\
\% change & $112.5 \%$ & $65.6 \%$ & & $71 \%$ & $190.5 \%$ \\
\hline
\end{tabular}

\section{Discussion}

The findings of this study support the overall cost escalation at both DI and DIII levels over time, provide insight into budget variables that predict Directors' Cup success, and offer insight on the cost-benefit of spending in athletics. In Division I, the strong positive correlation among athletics department budget variables suggests that athletics department spending is consistent across salaries, recruiting, and operating expenses within universities. In other words, schools with the largest budgets typically spend relatively large amounts across budget categories. Conversely, schools with smaller budgets spend relatively less across these categories. This finding for Division I schools is not surprising, nor is it surprising that this relationship holds over time (i.e., 2003-2011). Division I programs are the most highly commercialized of the NCAA divisions with the greatest revenues. Consistent with university (and athletics program) designations as nonprofit organizations, it is expected that athletics departments spend revenues in support of their missions, with spending in each budget category viewed as an input into the ultimate goal of on-the-field success. The strong correlations between budget variables and Directors' Cup rankings and the strong predictive ability of the regression model suggest that increased spending does lead to success, which — while also not surprising - underscores the problems inherent in the college sport arms' race. The conventional wisdom is that programs that spend more are more successful is supported by the study, and consequently, each program faces pressure to spend more to keep up with its peers. Ultimately, the amount a program can spend is limited by its own resources, but the pressure remains. This can cause athletics departments to increase their demands for external sources of revenues, such as student fees, institutional support, and public subsidization.

For DIII, the results of this study show that we see a similar trend of cost escalation across budget categories as the trend observed in Division I. However, the scale of athletics department expenditure is smaller, and budget variables appear to have less influence on the success of DIII schools as compared with DI schools. This suggests that, while budget variables should not be discounted, other factors at the DIII level can lead to success. Students at DIII schools do not receive scholarships, and factors such as the reputation of the school and reputation of the athletics program likely can play an important role in success at this level.

Finally, the results of our preliminary cost-benefit analysis show that there is a wide range of Directors' Cup points earned per dollar spent at DI and DIII. The most successful programs are not necessarily the most efficient (as evidenced by the moderate correlation), and to some extent, an athletics department can increase 


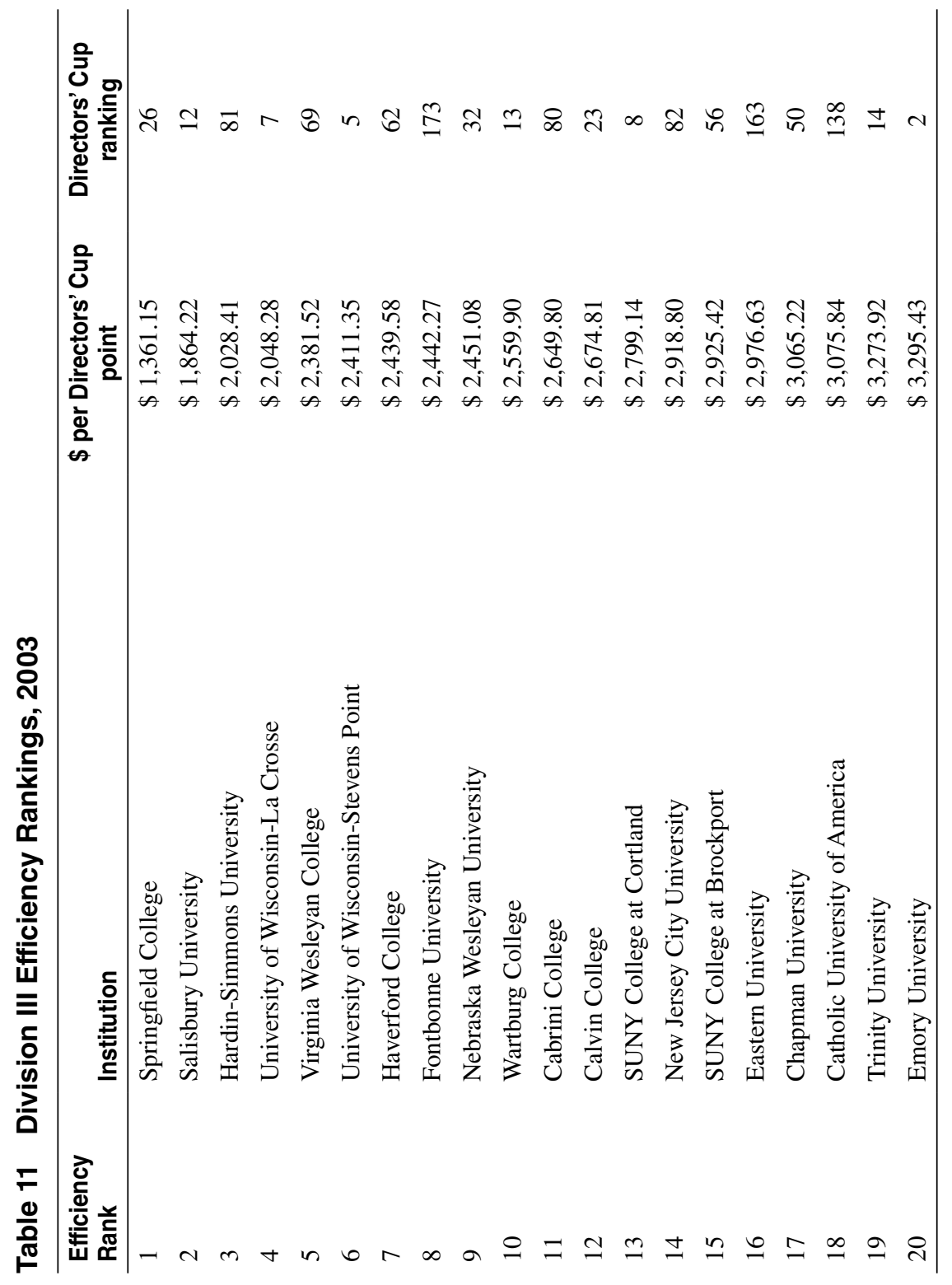




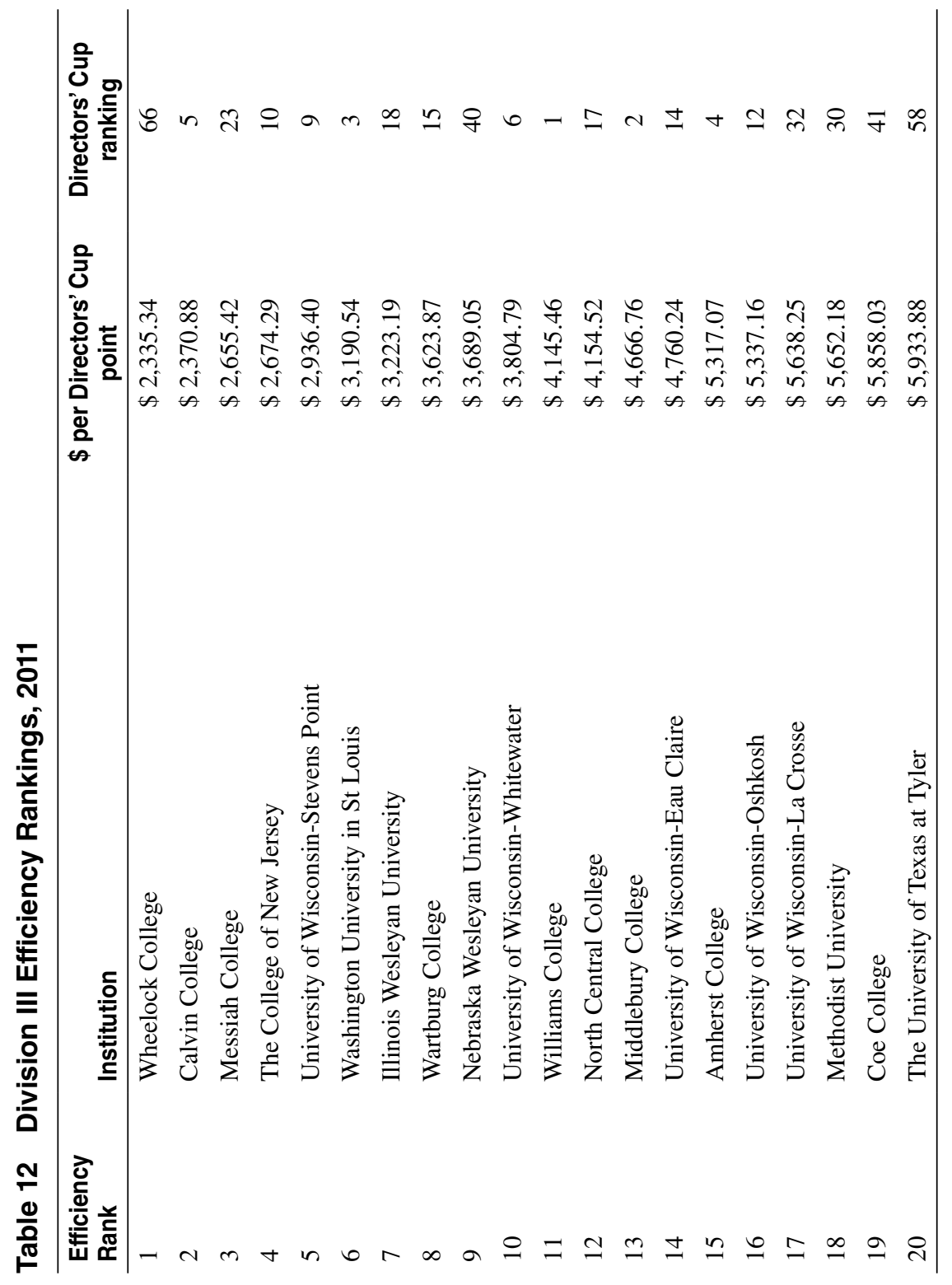


on-the-field success by spending more money, especially at the Division I level. However, the failure to consider efficiency will perpetuate the current cost escalation and has repercussions for the financial sustainability of programs. There appear to be some economies of scale to be realized-both at the conference level at the university system level. That is, it appears some universities have an advantage in terms of cost-savings and perhaps cost-sharing due to their affiliations. In Division I, most conferences already engage in some form of revenue sharing among member schools. In 2011, the Big Ten was the most valuable conference in Division I. One of its schools was ranked in the top ten of Directors' Cup points (Ohio State), and none of the Big 10 schools were ranked in the top 20 in terms of dollars per Directors' Cup points. The Pac-12 and the ACC are the second and third most valuable conferences in Division I, and their success based on cost-benefit analysis (and the Big 10's relative failure) suggests that the Pac-12 and the ACC have identified ways to capitalize on conference economies of scale to give the conference as a whole a competitive advantage in resource management. At the Division III level, the results of this study suggest that economies of scale can also be exploited within a university system, as evidenced by the University of Wisconsin's relatively efficient allocation of financial resources to produce wins. More comprehensive cost-benefit evaluation of athletics departments could help to identify best practices of efficient organizations, which can help insulate a program in the face of a continued economic downturn, reduced donations, or some other financial or budgetary shock.

\section{Practical Recommendation}

The results point to operating expenses as the strongest predictor of success for both DI and DIII schools in 2003 and 2011. In both years and divisions, operating expenses was consistently a significant predictor of on-the-field success on its own. Thus, investing in operating expenses over salaries and recruiting expenses would likely produce the greatest gains in on-the-field success. Interestingly, on its own head coaching salaries were not a significant predictor of success. This finding is supported by previous research (e.g., e.g., Cunningham, 2003; Orszag \& Israel, 2009; Tsitsos \& Nixon, 2012; Zimbalist, 2010), but it should be noted that salary has been found to be a "Industry Standard factor" for coaches and will lead to dissatisfaction if a certain threshold is not met (Dixon \& Warner, 2010). Therefore, it is recommend at coaches be fairly compensated as throwing more money at coaches will not likely improve performance or satisfaction while undercompensating coaches will lead likely to dissatisfaction.

Similar to head coaching salaries, recruiting expenses alone did not significantly predict on-the-field success. Again though, simply decreasing recruiting expenses likely could have negative consequences. Recent work has demonstrated that it is important that student-athletes perceive that an equitable environment exists (e.g., Sartore-Baldwin \& Warner, 2012; Warner \& Dixon, 2011). Since recruiting expenses are likely most visible to student-athletes, again it is recommend that equitable spending across the department and with competitors is perceived. Thus, drastically decreasing or increasing recruiting expenses will likely result in little positive gain for an athletics department. Recruiting high-quality and skilled athletes is a major aspect of creating a successful athletics program. Therefore, it is not surprising 
that recruiting expenses are a large part of the ever-increasing athletics budgets. Although many factors are involved in recruiting student-athletes, the money available to be used for recruiting purposes is viewed as essential to coaches and administrators trying to attract top athletes. However, this study demonstrates that recruiting expenses alone did not significantly predict success.

Overall this study supports that increased spending can result in increased on-the-field success; however, little evidence exists on the sustainability of this approach. As the trends highlighted in this study demonstrate, expenses are continuing to grow. Although this study focused on expenses as an input to athletics success, it is worth noting that the vast majority of athletics departments still operate at a loss. This suggests that department revenues are not keeping pace with cost escalation. Thus, it is important to understand the relationship between athletic department success and revenue generation or lack thereof. In addition, athletics departments are believed to confer various intangible benefits to the university, including increased donations (Anderson, 2012; Getz \& Siegfried, 2010) and larger application pool (Litan, Orszag, \& Orszag, 2003). However, there is conflicting evidence as to whether universities realize these benefits as a result of success. Both the link between athletics department success and revenue generation and the existence and scale of intangible benefits merit further exploration to assess the viability and value of athletics programs.

\section{Conclusion}

There is widespread agreement among athletics department and university personnel and academics that the cost escalation in college athletics is worthy of investigation and is likely to be unsustainable. The results of this study underscore the strength of the relationship between operating expenses and on-the-field success at the Division I level, and salaries and recruiting expenses to a lesser degree. At the Division III level, while selected budget variables are related to on-the-field success, they have less predictive value, as compared with Division I. Finally, schools with athletics success are not necessarily the schools that use their resources most efficiently.

\section{References}

Alesia, M. (2009, July). 3 lawsuits may change how NCAA operates. Indianapolis Star. Retrieved from http://usatoday30.usatoday.com/sports/college/2009-07-26-ncaalawsuits_N.htm

Alexander, F.K. (2000). The changing face of accountability: Monitoring and assessing institutional performance in higher education. The Journal of Higher Education, 71, 411-431. doi:10.2307/2649146

Anderson, M. (2012). The benefits of college athletics success: An application of the propensity score design with instrumental variables. NBER Working Paper No. 18196. Cambridge, MA: National Bureau of Economic Research.

Barr, C. (2012). Collegiate Sport. In L. Masteralexis, C. Barr, \& M. Hums (Eds.), Principles and practice of sport management (pp. 163-185). Sudbury, MA: Jones \& Bartlett Learning.

Barr, N. (2004). Higher education funding. Oxford Review of Economic Policy, 20, 264-283. doi:10.1093/oxrep/grh015 
Brady, E., Berkowitz, S., \& Upton, J. (2012, November 20). College football coaches continue to see salary explosion. USA Today. Retrieved from http://www.usatoday.com/

Brady, E., Upton, J., \& Berkowitz, S.(2013, March 6). Major college ADs averaging more than $\$ 500,000$ in pay. USA Today. Retrieved from http://www.usatoday.com/

Byers, W. (1995). Unsportsmanlike Conduct: Exploiting College Athletes. Ann Arbor: University of Michigan Press.

Chu, D. (1989). The character of American higher education and intercollegiate sport. Albany: State University of New York Press.

Clotfelter, C.T. (2011). Big-time sports in American universities. Cambridge University Press.

Cook, B. (2012, August). Will 'pay to play' become a permanent part of school sports? Forbes. Retrieved from http://www.forbes.com/sites/bobcook/2012/08/22/will-payto-play-become-a-permanent-part-of-school-sports/

Covell, D., \& Barr, C.A. (2010). Managing intercollegiate athletics. Holcomb Hathaway, Publishers.

Cunningham, G. B. (2003). Human resources as sources of competitive advantage: A resource-based view of the athletic department. Applied Research in Coaching and Athletics Annual, 37-58.

Dealy, F.X. (1990). Win at any cost. New York: Carol Publishing Group.

Denhart, M., \& Ridpath, D. (2011). Funding the arms race: A case study of student athletic fees. Center for College Affordability and Productivity.

Dixon, M.A., \& Warner, S. (2010). Employee satisfaction in sport: Development of a multidimensional model in coaching. Journal of Sport Management, 24, 139-168.

Fort, R. (2010). An economic look at the sustainability of FBS athletic departments. Journal of Intercollegiate Sport, 3, 3-21. doi:10.1177/1527002509354889

Fulks, D.L. (2011). Revenues \& Expenses 2004-2010: NCAA Division I Intercollegiate Athletics Programs Report. Indianapolis, IN: National Collegiate Athletic Association.

Fulks, D.L. (2012). 2004-2011 Revenues and Expenses of NCAA Division III Intercollegiate Athletics Programs Report. Indianapolis, IN: National Collegiate Athletic Association.

Getz, M., \& Siegfried, J.J. (2010). What does intercollegiate athletics do to or for colleges and universities. Nashville, TN: Vanderbilt University, Department of Economics. Retrieved from http://www.accessecon.com/pubs/VUECON/vu10-w05.pdf.

Hesel, R., \& Perko, A. (2010). A sustainable model? University presidents assess the costs and financing of intercollegiate athletics. Journal of Intercollegiate Sport, 3, 32-50.

Humphrey, J.H., Yow, D.A., \& Bowden, W.W. (2000). Stress in College Athletics: Causes, Consequences, Coping. Binghamton, NY: Haworth Half-Court Press, Inc.

Jones, W. A. (2012). Exploring the relationship between intercollegiate athletic expenditures and team on-field success among NCAA Division I Institutions. Journal of Sports Economics.

Knight Foundation Commission on Intercollegiate Athletics. (1991). Keeping faith with the student-athletes: A new model for inter-collegiate athletics. Charlotte, NC: Knight Foundation.

Knight Foundation Commission on Intercollegiate Athletics. (2001). A call to action: Reconnecting college sports and higher education. Miami: Knight Foundation.

Knight Foundation Commission on Intercollegiate Athletics. (2010). Restoring the balance: Dollars, values and the future of college sports. Miami: Knight Foundation.

Lawrence, H.J., Li, M., Regas, J.S., \& Kander, J. (2012). National Association of Collegiate Directors of Athletics Directors' Cup Standings: Predictors of Success. Journal of Issues in Intercollegiate Athletics, 5, 207-224.

Litan, R.E., Orszag, J.M., \& Orszag, P.R. (2003). The empirical effects of collegiate athletics: An interim report. Belmont, CA: Sebago Associates.

Lubinger, B. (2011, October). College sports teams are big business, and some coaches are cashing in. The Plain Dealer. Retrieved from http://www.cleveland.com/datacentral/ index.ssf/2011/10/college_sports_teams_are_big_b.html 
Masteralexis, L., Barr, C., \& Hums, M. (2012). Principles and practice of sport management (4th ed.). Sudbury, MA: Jones \& Bartlett Learning.

National Association of Collegiate Directors' of Athletics. (2012). Learfield sports directors' cup general information. Retrieved from http://nacda.cstv.com/directorscup/ nacda-directorscup.html

Orszag, J.M., \& Israel, M. (2009). The empirical effects of collegiate athletics: An update based on 2004-2007 data. National Collegiate Athletic Association.

Powers, E. (2007, May 15). Tracking sports spending. Inside Higher Ed. Retrieved from http://www.insidehighered.com/news/2007/05/15/knight

Sartore-Baldwin, M., \& Warner, S. (2012). Perceptions of inequities among intercollegiate athletes: Does social justice matter? Journal of Issues in Intercollegiate Athletics, 269-282.

Smith, R.A. (1988). Sports and freedom: The rise of big-time college athletics. New York, NY: Oxford University Press.

Sparvero, E.S., Chalip, L., \& Green, B.C. (2008). United States. In B. Houlihan \& M. Green (Eds.), Comparative elite sport development: Systems, structures, and public policy. Burlington, MA: Butterworth - Heinemann.

Tsitsos, W., \& Nixon, H.L., II. (2012). The star wars arms race in college athletics Coaches' pay and athletic program status. Journal of Sport and Social Issues, 36(1), 68-88. doi:10.1177/0193723511433867

U.S. Department of Education. (2012). Equity in Athletics Disclosure Act (EADA) Website. Retrieved from http://ope.ed.gov/athletics/

Warner, S., \& Dixon, M.A. (2011). Understanding sense of community from an athlete's perspective. Journal of Sport Management, 25, 258-272.

Warner, S., Shapiro, S., Dixon, M.A., Ridinger, L.L., \& Harrison, S. (2011). The football factor: Shaping community on campus. Journal of Issues in Intercollegiate Athletics, 4, 236-256.

Yaffee, A. (April, 2005) Athletic funding concerns Brand, NCAA. Duke Chronicle. Retrieved from: http://www.dukechronicle.com/articles/2005/04/20/athletic-funding-concernsbrand-ncaa

Zimbalist, A. (2010). Circling the Bases: Essays on the Challenges and Prospects of the Sports Industry. Temple University Press. 